\title{
A Submerged Serrated Lesion in the Appendix Rest as Identified by the "Cecal Mucus Sign" and Forceps Exposition
}

\author{
Vincent Zimmer ${ }^{a, b}$ Elke Eltze ${ }^{c}$

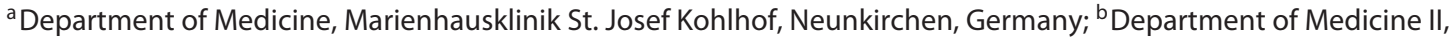

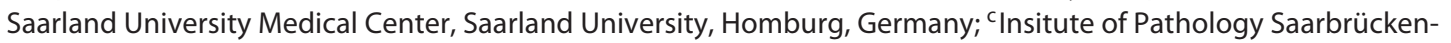 \\ Rastpfuhl, Saarbrücken, Germany
}

\section{Keywords}

Screening colonoscopy · Colorectal cancer · Appendix ·

Appendectomy · Endoscopic resection

\section{Uma Lesão Serreada Submersa no Coto Apendicular Identificada Pelo "Sinal de Muco no Cego" e Exposição Com Pinça}

\section{Palavras-chave}

Colonoscopia de rastreio · Cancro colorretal · Apêndice · Apendicectomia $\cdot$ Resseção endoscópica

A 66-year-old female patient presented for screening colonoscopy after an incomplete office-based procedure due to failed sigmoid passage. Medical history included hysterectomy with adnexectomy and appendectomy. Apart from cecal angiodysplasias, a tenacious mucus lake was detected at the appendix base ("cecal mucus sign") [1, 2] (Fig. 1a). After extensive washings, at first, no clear-cut mucosal abnormality was identified by white light and image-enhanced endoscopy (Fig. 1b, c). Only after manipulation by a standard biopsy forceps, a submerged lesion was unmasked, pathologically confirmed as a sessile serrated adenoma/polyp (SSA/P) without dysplasia (Fig. 1d). In consideration of her significant surgical his-

karger@karger.com www.karger.com/pjg

Karger"

BOPEN ACCESS
(C) 2020 Sociedade Portuguesa de Gastrenterologia

Published by S. Karger AG, Basel

This article is licensed under the Creative Commons AttributionNonCommercial-NoDerivatives 4.0 International License (CC BYNC-ND) (http://www.karger.com/Services/OpenAccessLicense). Usage and distribution for commercial purposes as well as any distribution of modified material requires written permission. tory, nota bene including appendectomy, and significant obesity (BMI $43.0 \mathrm{~kg} / \mathrm{m}^{2}$ ), we abstained from up-front surgery for this benign colorectal lesion, and the patient consented to undergo endoscopic resection [3]. However, the intended device-assisted endoscopic full-thickness resection (EFTR) could not be performed due to lack of passage through the sharply angulated sigmoid by the full-thickness resection device (FTRD) test cap (FTRD prOVE Cap, Ovesco, Germany) [4]. Beyond the previously detected small sessile lesion, the full lesion extent was, at the time, visualized after ineffective submucosal indigo carmine injection related to exuberant postsurgical fibrosis and acetic acid spraying, albeit as yet with lowlevel evidence, highlighting the serrated lesion and its borders $[5,6]$. The appendix rest was, in addition, distended by underwater endoscopy, revealing a carpet-like involvement with a diffusely velvety appearance (Fig. 1e). Albeit post-piecemeal endoscopic mucosal resection (pEMR) surveillance has been scheduled in 9 months and is, thus, still pending, presumably complete pEMR was achieved by cold snare resection of sessile parts, and an uncomplicated (standard) cap-assisted aspiration mucosectomy of the remaining appendix (Fig. 1f). Visualization of the resection bed excluded deep mural injury and/ or bleeding-prone vessels, thus clip-closure of the defect was not warranted, and the patient took an uncompli- 

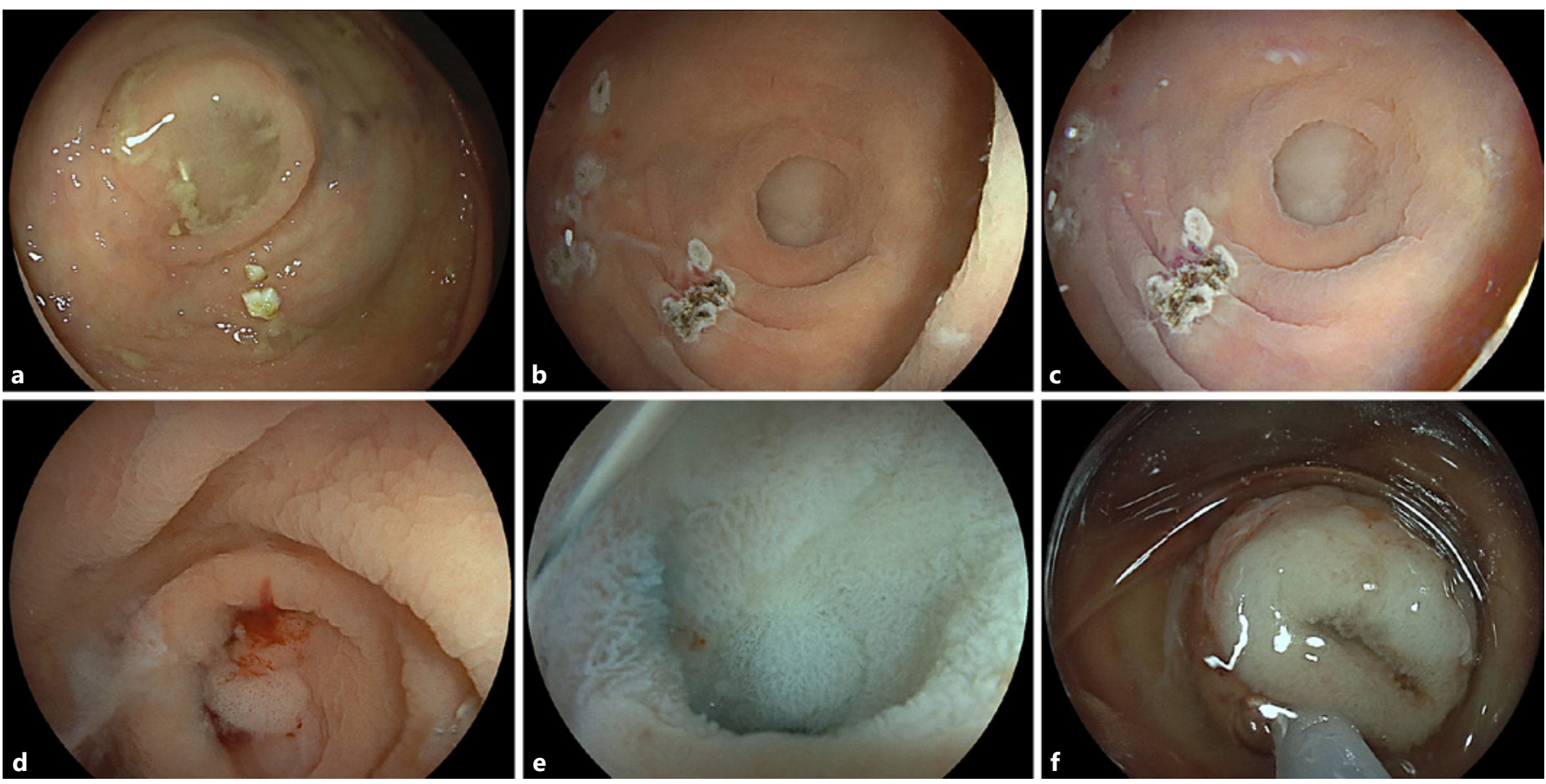

Fig. 1. a A "cecal mucus sign" was identified during screening colonoscopy. b, c After extensive washings, no clear-cut mucosal abnormality was identified by white light and image-enhanced endoscopy - note argon plasma coagulation (APC) sites due to cecal angiodysplasias. d Only after forceps manipulation, a submerged lesion was unmasked, pathologically confirmed as a sessile serrated adenoma/polyp (SSA/P) without dysplasia. e Beyond previously detected small sessile parts, the full lesion extent was visualized after acetic acid spraying and underwater endoscopy, revealing a carpet-like involvement with a diffusely velvety appearance. $\mathbf{f}$ Endoscopic piecemeal resection was achieved by cold snare resection and cap-assisted aspiration mucosectomy.

cated clinical course. Notwithstanding that recent data indicate feasibility of simple EMR in appendiceal lesions involving $<50 \%$ of the circumference with an identifiable proximal extension, the presented clinical report is unique in terms of status post-appendectomy as well as a carpetlike, utterly flat extension of an estimated 15 -mm serrated lesion occupying the whole appendix rest [7].

\section{Statement of Ethics}

Patient consent has been obtained for the publication of this report, including images.

\section{Conflict of Interest Statement}

The authors have no conflicts of interest to declare.

\section{References}

1 Behary J, Hui JM. The caecal mucus sign. Gut. 2018 Feb;67(2):298.

2 Figueroa-Rivera IM, Santiago-Rivera L, Magno P. Sessile Serrated Adenoma of the Appendix in an Asymptomatic Patient. Clin Gastroenterol Hepatol. 2018 Apr;16(4):A27.

3 Dumoulin FL, Gorris DG, Berger S, Hildenbrand R, Sido B. Full-thickness resection with an over-the-scope device: possible translocation of adenoma tissue in a case of an incomplete resection at the appendix. Endosc Int Open. 2018 May;6(5):E622-4.
4 Zimmer V, Heinrich C. The "Doughnut Sign" Indicating Base Appendectomy in DeviceAssisted Endoscopic Full-Thickness Resection. Am J Gastroenterol. 2019 Aug;114(8): 1192.

5 Yamamoto S, Varkey J, Hedenström P. Acetic acid spray for better delineation of recurrent sessile serrated adenoma in the colon. VideoGIE. 2019 Aug;4(12):547-8.
6 Wiessner JR, Brown H, Haller B, Abdelhafez M, Poszler A, Schmid RM, et al. Near focus NBI endoscopy plus acetic acid for optical polyp characterization in the colorectum - A proof of principle study. Scand J Gastroenterol. 2019 Mar;54(3):377-83.

7 Tate DJ, Desomer L, Awadie H, Goodrick K, Hourigan L, Singh R, et al. EMR of laterally spreading lesions around or involving the appendiceal orifice: technique, risk factors for failure, and outcomes of a tertiary referral cohort (with video). Gastrointest Endosc. 2018; 87(5):1279-88.e2. 